\title{
Eksegese van 2 Petrus 3:1-2 en die hermeneuse daarvan met spesifieke verwysing na standpunte van die sogenaamde Nuwe Ateïste
}

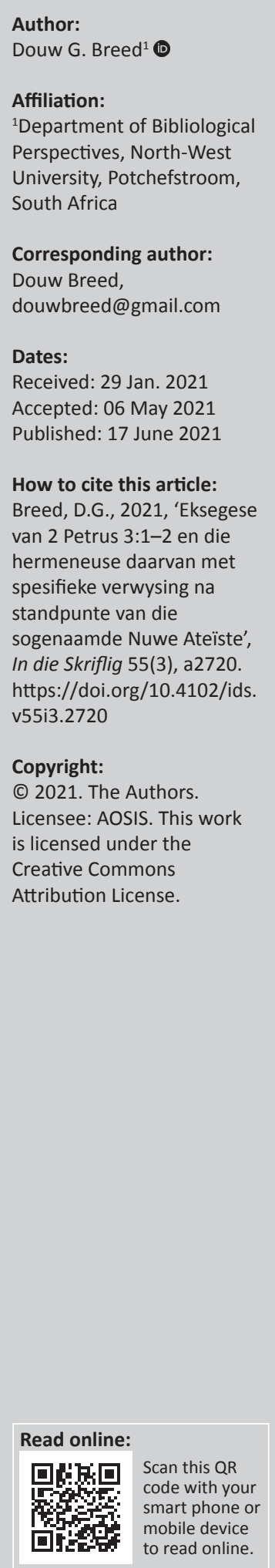

Exegesis of 2 Peter 3:1-2 and its significance for contemporary Christians with specific reference to views of the so-called New Atheists. Die Bybel: 2020-vertaling, in Afrikaans translation of the Bible, has been introduced at a time when the Bible, the God of the Bible and believers who accept the Bible as the Word of God are seriously under suspicion. The question is how Christians are supposed to act and react in the light of these developments. The religious conviction of Peter's first readers was under great pressure as a result of false teachers. This article exegetically indicates the guidance that Peter gives to his readers according to 2 Peter 3:1-2 and points out its significance for contemporary Christians. The exegesis in the article is concentrated on 2 Peter 3:1-2 within the context of the letter and is done according to the grammatical-historical model as practised in the Reformed tradition. The article cites examples of the New Atheists' questioning of the Christian faith. Reference is then made to 2 Peter 3:1-2, regarding what believers must do when their faith is questioned. The article found that Christians today, like Peter's first readers, are still under great pressure because of atheists' hostile actions. Like Peter's first readers, modern-day believers need guidance so that they do not succumb to the pressures on their steadfastness. Christians must think purely of the Old Testament prophets and the apostles of Jesus Christ and the revelation they received from God and Jesus Christ. When Christians think purely about prophets and apostles, they will understand the meaning of these people's message in their present circumstances and will be able to act appropriately. 2 Peter 3:1-2 provides guidance to Christians whose faith is under pressure due to the hostile actions of unbelievers.

Contribution: The article contributes to the understanding of the guidance that Peter gave to his first readers according to 2 Peter 3:1-2 and provides guidance to Christians whose faith, like Peter's first readers, is being questioned.

Keywords: 2 Peter 3:1-2; New Atheists; Richard Dawkins; faith steadfastness; prophets; apostles; Bible; Christian believers.

\section{Inleiding}

Die Bybel: 2020-vertaling word in 'n tyd bekend gestel waarin die Bybel, die God van die Bybel en gelowiges wat die Bybel as die Woord van God aanvaar, ernstig onder verdenking geplaas word. Gordon (2008:2) sê dat selfs in lande met 'n Christelike tradisie, die houding teenoor die Christendom 'moved from indifference to open disrespect and even ridicule'. Ook Blaising (2012:391) wys daarop dat die Christelike wêreldbeskouing vandag in 'n groot mate deur naturalisme vervang is. Die vraag is dan wat Christene in die lig van hierdie verwikkelings te doen staan.

In sy tweede brief aan die gelowiges in Klein-Asië bestry Petrus ${ }^{1}$ mense wat hy vals leraars

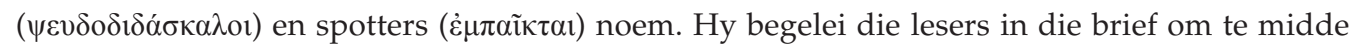
van die leraars en spotters nie hulle standvastigheid (vgl. $\sigma \tau \eta \rho \gamma \mu$ ó, , 3:17) in die geloof te verloor nie. In hierdie artikel val die klem op die leiding wat die apostel spesifiek in 2 Petrus 3:1-2, binne die konteks van die hele brief, aan die lesers gee. Ter wille van bondigheid, word die hermeneuse ${ }^{2}$ wat in hierdie artikel aangebied word, gerig op standpunte van die ateïste Richard 1.Vergelyk Breed (1994:11-26), Kruger (1999:645-671) en Van Houwelingen (2010:119-129) wat aantoon dat die tweede Petrus-brie deur die apostel Petrus geskryf is.

2.Met die term hermeneuse word na die proses verwys waarvolgens die skrywer van die teks se oorspronklike bedoeling na die werklikheid van vandag oorgebring word (vgl. Coetzee, De Klerk \& Floor 1980:12-26). 
Dawkins, Daniel Dennett, Sam Harris en Christopher Hitchens wat as die 'New Atheists', of as die 'Four Horsemen' ${ }^{\prime 3}$ bekend staan. Hierdie skrywers is oortuig dat 'science, in short, has put religion, including philosophy of religion, out of business for good' (Feser 2013:155).

Alhoewel daar in die hermeneuse in die artikel verskeie standpunte van die vier Nuwe Ateïste aangedui word, is hierdie artikel nie apologeties van aard nie. Die artikel poog eerder om aan die hand van voorbeelde waarin die Nuwe Ateïste die Christelike geloof skerp bevraagteken, in die eksegese en hermeneuse van 2 Petrus 3:1-2 leiding te gee aan Christene wat in 'n wêreld leef waarin hulle geloof met disrespek en selfs spot, verwerp word.

In die eksegese en hermeneuse wat in hierdie artikel aangebied word, volg die outeur die grammaties historiese model wat in die gereformeerde tradisie beoefen word (vgl. Breed, Van Rensburg \& Jordaan 2008:45-53; Fee 2009:29-132; Jordaan, Van Rensburg \& Breed 2011:225-258; Tolar 2002:21-38). Om die betekenisse waarvoor Griekse woorde gebruik word, na te gaan, word die metode van komponensiële analise gevolg (vgl. Breed 1994:6-7; Louw \& Nida 1988:vi-xx). In die ontleding van die gedagtestruktuur van 2 Petrus word die metode van Coetzee (1988:19-37) soos dit ook deur Breed (1994:4-5) gebruik is, aangewend.

In hierdie artikel word eerstens aan die tekstuele konteks van 2 Petrus 3:1-2 aandag gegee, en tweedens aan die leraars-spotters ${ }^{4}$ en die doel van Petrus se skrywe soos dit in 3:1-2 vermeld word. In die derde plek word Petrus se

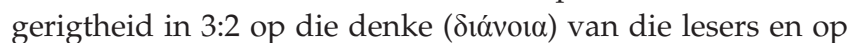
herinnering (író $\mu v \eta \sigma \iota \varsigma)$ aan die orde gestel. Vervolgens

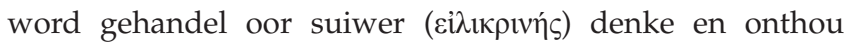
$(\mu \mu v \underline{\sigma} \sigma \kappa о \mu \alpha)$ wat in 3:2 genoem word. Aan die einde van die artikel word tot 'n slotsom gekom.

\section{Kontekstuele konteks van Petrus 3:1-2}

Breed (1994:45-77) toon aan dat die tweede brief van Petrus in die volgende gedagte-eenhede ingedeel kan word:

- Aanhef (1:1-2);

- Opsomming van die apostel se leer (1:3-11);

- Die doel van die skrywe (1:12-15);

- Fundering van die apostels se gesag (1:16-21);

- Waarskuwing met betrekking tot die vals leraars (2:1-22);

- Die doel van die skrywe (3:1-2);

- Die Here se koms en die sekerheid daarvan (3:3-18);

- Die brief se slot (3:17-18a);

- Lofprysing (3:18b).

3.Vir' $n$ nadere beskrywing van die terme 'New Atheists' en 'Four Horsemen', vergelyk Johnson (2013:5-6) en Zenk (2013:251-252); en vir 'n kort opsomming van die Nuwe Ateïste se standpunte, vergelyk Haught (2008:xiii-xiv).

4.Die vals leraars wat in 2 Petrus 2:1-22 beskryf word en die spotters waarna in 3:3 verwys word, is dieselfde mense (Moo 2011:165). Daar word dus in hierdie artike na leraars-spotters verwys.
Uit die gedagtestruktuur kan twee afleidings gemaak word wat in die eksegese en hermeneuse van 3:1-2 in ag geneem behoort te word:

- Gedagte-eenhede 3:1-2 en 1:12-15 is baie nóú aan mekaar verbind. In beide dui die skrywer die doel van sy skrywe aan.

- 3:1-2 word voorafgegaan deur 'n gedagte-eenheid waarin die lesers uitgebreid (2:1-22) teen vals leraars gewaarsku word. Die doel van die brief, soos Petrus dit in 3:1-2 beskryf, hou klaarblyklik verband met die waarskuwing wat hy in 2:1-22 tot die lesers rig.

\section{Die leraars-spotters en Petrus se doel met sy skrywe}

Uit 2:1-22 kan verskeie redes aangedui word waarom Petrus hom volgens 3:1-2 ten doel stel om sy lesers suiwer te laat dink. Petrus is eerstens van oordeel dat die vals leraars baie mense deur hulle verkondiging sal oortuig. Hy sê in 2:2 dat baie ( $\pi$ o $\lambda u ́ \varsigma)$ die leraars sou volg (Davids 2006:222).

Die feit dat Petrus die vals leraars ( $\left.\psi \varepsilon v \delta \circ \delta \delta \delta \alpha ́ \sigma \kappa \alpha \lambda \circ \varsigma_{,}, 2: 1\right)$ in 3:3 spotters ( $(\dot{\varepsilon} \mu \pi \alpha i ́ \kappa \tau)$ ) noem en sê dat hulle met spot (vgl. die datief

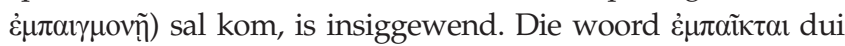
iemand aan wat spottend optree (Louw \& Nida 1988:435) en die woord $\dot{\varepsilon} \mu \pi \alpha \gamma \mu$ oví wys op die bespotlike voorstelling van iemand (vgl. Louw \& Nida 1988:435). Die leraars-spotters word in 3:3 aangedui as 'people who scorn and despise God's revelation, both moral and prophetic', wat die 'predictions of the prophets and the apostolic commandment' verwerp het en die 'Parousia hope' bespotlik voorgestel het (Bauckham 1983:288-289). Deur hierdie bespotting het die leraars-spotters druk op mense geplaas om af te sien van standpunte wat met hulle eie standpunte verskil.

Die leefwyse van die leraars-spotters wat Petrus in 3:3 vermeld, naamlik dat hulle hul lewe volgens hulle eie drange inrig, het 'n aantrekkingskrag vir mense gehad. Petrus sê in 2:18 dat die leraars-spotters mense tot sonde verlei (vgl. Louw \& Nida 1988:775 vir die betekenis waarna $\delta \varepsilon \lambda \varepsilon \alpha ́ \zeta \omega$ verwys). Die middel wat hulle gebruik het, is mense se sondige liggaamlike begeertes

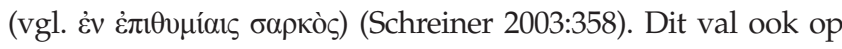
dat Petrus in 2:2 noem dat die mense wat hierdie leraarsspotters sou volg, juis hulle morele bandeloosheid ( $\dot{\alpha} \sigma \dot{\delta} \lambda \gamma \varepsilon ı \alpha)$ sou navolg (Davids 2006:222).

Volgens 2:18 het die leraars-spotters mense ook deur hulle woorde verlei. Die skrywer beskryf hulle woorde met die

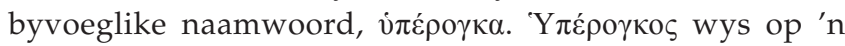
uitermatige gespog (Louw \& Nida 1988:432). Hierdie mense het dus met groot selfvertoue gepraat, en noem Schreiner (2003:358), 'those who are weak are often susceptible to the assertive confidence of others, even if such confidence flows from arrogance and $\sin ^{\prime}$.

Gedagte-eenheid 2:1-22 laat blyk dat die leraars-spotters spesifieke mense geteiken het in hulle poging om mense tot hulle standpunte en lewenswyse te oortuig: 
- In 2:14 wys Petrus op die leraars se sukses met mense wat onstandvastig (ג் wys op ' $n$ tendens om te verander, of om onseker te wees in jou houding of oortuigings (Louw \& Nida 1988:376). Die leraars-spotters het sulke mense tot sonde verlei

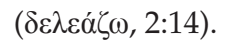

- Die leraars-spotters het ook mense geteiken wat pas tot geloof gekom het. Petrus verwys in 2:18 na mense wat onlangs (ỏ $\lambda \hat{i} \gamma \omega \varsigma$, vgl. Davids 2006:245; Louw \& Nida 1988:690; Schreiner 2003:357) vrygekom het van diegene wat in dwaling leef. Die leraars het mense wat onlangs tot geloof gekom het, tot sonde verlei ( $\delta \varepsilon \lambda \varepsilon \alpha \dot{\zeta} \omega, 2: 18)$.

- Die mense wat in hulle geloof standvastig was, was ook kwesbaar vir die verleiding deur die leraars-spotters. In 1:12 sê Petrus dat die lesers reeds sy leer, wat hy in 1:3-11 opsom, ${ }^{5}$ ken en ook dat hulle vasstaan in die Christelike leer. ${ }^{6}$ Petrus ag dit volgens 1:12 egter steeds nodig om die lesers altyd (åzí) aan sy leer te herinner. Ook uit 3:17 kan afgelei word dat standvastigheid nie 'n waarborg is teen die valsheid van die leraars-spotters nie. Petrus waarsku in 3:17 die lesers wat standvastig is, om te waak dat hulle nie hulle standvastigheid verloor nie.

Hoewel die leraars-spotters wat Petrus beskryf, anders as die Nuwe Ateïste, nie God se bestaan ontken het nie, is Petrus se beklemtoning van die sukses van die leraars-spotters en hulle gerigtheid op sekere groepe, asook die kwesbaarheid van die lesers, vir hedendaagse Christene relevant. Die Nuwe Ateïste slaag ook daarin om mense tot hulle oortuigings te oorreed en volgelinge te werf. Die gewildheid van Dawkins (2009) se boek, The God delusion waarin hy die bestaan van God ontken, spreek boekdele. Joseph (2020:52) noem dat meer as drie miljoen kopieë van hierdie boek wêreldwyd verkoop is, en dat dit in meer as 35 tale vertaal is. Die aantrekkingskrag van die Nuwe Ateïste se standpunte word goed deur Angier (2004) verwoord in haar evaluering van Sam Harris se boek, The end of faith, religion, terror and the future of reason. Sy (Angier 2004) skryf: 'The End of Faith articulates the dangers and absurdities of organized religion so fiercely and so fearlessly that I felt relieved as I read it, vindicated, almost personally understood'.

Dat die Nuwe Ateïste daarop uit is om mense tot ateïsme oor te haal, kan gesien word wanneer Dawkins (2009:28) oor sy boek, The God delusion, sê: 'If this book works as I intend, religious readers who open it will be atheists when they put it down'. Harris (2019:55-56) wys daarop dat die Nuwe Ateïste op verskeie wyses poog om mense tot ateïsme te oorreed. Hy noem dat Dawkins, Dennett, Harris en Hitchens moeite doen om in die media publisiteit vir hulle oortuigings te verkry. Dawkins het volgens Harris ook as een van die borge van die rooibus-veldtog opgetree. Tydens hierdie veldtog het die busse in Londen advertensies gedra wat verkondig het dat mense as gelukkige ateïste kan leef. Laing (2011:14) noem dat honderde en selfs duisende blogs

5. $r \varepsilon p i$ toútwv in $1: 12$ verwys na die leer van die apostel wat hy in 1:3-11 opsom (Bauckham 1983:197).

6. $\dot{\alpha} \lambda \dot{\theta} \theta \varepsilon\llcorner\alpha$ in $1: 12$ verwys na die evangelie wat aan die lesers verkondig is (Green 2008:209210). en video's gemaak word wat die argumente van die Nuwe Ateïste ondersteun. Hy sê 'these are read and viewed by strong believers and unbelievers, as well as those we may deem, "the undecided"'.

Uit die publikasies van die Nuwe Ateïste blyk dit dat hulle ook gerig is op sekere groepe mense wat kwesbaar is vir hulle ateïstiese oortuigings. Die Nuwe Ateïste is byvoorbeeld daarop ingestel dat die jeug se denke verander moet word. Hulle trek daarom te velde teen enige religieuse onderrig aan kinders. Hitchens (2007:220) is daarvan oortuig dat, indien geen religieuse onderrig toegelaat sou word nie 'until the child had attained the age of reason, we would be living in a quite different world.' Dawkins (2009:367) haal die ateïs Nicholas Humphrey met instemming aan wat naamlik sê, dat ouers net so min toegelaat moet word om hulle kinders die 'literal truth of the Bible' te leer, as wat ouers toegelaat moet word 'to knock their children's teeth out or to lock them in a dungeon'. 'n Tweede groep tot wie die Nuwe Ateïste toegang verkry, is 'those of us who have internalized the scientific frame of reference' (Nürnberger 2010:19). Nürnberger wys daarop dat Dawkins se argumente, naamlik dat 'the notion of God lacks evidence, coherence, explanatory power, utility, ethical integrity and genuine comfort', 'n besondere aantrekkingskrag het vir Christene wat in 'n wetenskaplike kultuur leef.

Soos dit die geval was met die leraars-spotters wat Petrus bestry, is daar ook by die Nuwe Ateïste geen gebrek aan selfversekerdheid nie. Hitchens (2007) skryf meerderwaardig dat religie:

[C]omes from the bawling and fearful infancy of our species, and is a babyish attempt to meet our inescapable demand for knowledge (as well as for comfort, reassurance, and other infantile needs). Today the least educated of my children knows much more about the natural order than any of the founders of religion ... (p. 64)

Dawkins (2009:57) sê: ‘I am attacking God, all gods, anything and everything supernatural, wherever and whenever they have been or will be invented'. Walsh (2019:17-18RR) noem dat Dawkins, Dennett, Hitchens en Harris intellektueel begaafde en geartikuleerde leiers van die ateïste is. Hy noem hulle 'wordsmiths', en sê dat hulle hul leerstellings op so 'n wyse verkondig, dat 'people sit up and take notice (and buy their books)'.

Die Nuwe Ateïste stel hulle op 'n baie konfronterende styl teenoor enige religie - ook teenoor die Christelike godsdiens. Copan en Craig (2009:26RR) sê tereg, dat die Nuwe Ateïste as aggressiewe voorstanders van ateïsme, oortuig is dat religieuse mense op ' $n$ irrasionele manier met religie volhard en ook glo dat religieuse mense moreel skadelik is. Die konfronterende styl van die Nuwe Ateïste word sigbaar wanneer Harris (2005) sê:

The very ideal of religious tolerance - born of the notion that every human being should be free to believe whatever he wants about God - is one of the principal forces driving us toward the abyss. (pp. 14-15) 
Ook Dawkins (2009:50) laat geen twyfel dat hy oortuig is dat religie geen besondere respek verdien nie. Hy sê: 'I shall not go out of my way to offend, but nor shall I don kid gloves to handle religion any more gently than I would handle anything else'. Turek (2014:38) noem dat Dawkins mense by 'n saamtrek aangemoedig het om enige katolieke persoon wat in die nagmaal glo, te bespot. Dawkins het die mense by die byeenkoms aangepor met die woorde: 'Mock them! Ridicule them! In public!' (vgl. 'n video-opname van die gebeure by https://www. youtube.com/watch?v=uPqqp8KVuQU).

Uit voorgaande beredenerings kan afgelei word dat Christene vandag soos Petrus se eerste lesers, steeds met betrekking tot hulle geloof onder groot druk verkeer. Soos Petrus se eerste lesers, het hedendaagse gelowiges leiding nodig sodat hulle nie onder die druk swig en uit hulle standvastigheid meegevoer word nie.

\section{Die denke van die lesers en herinnering}

In die lig daarvan dat Petrus se lesers onder die druk van die leraars-spotters verkeer, en dat hulle moontlik hulle standvastigheid kon verloor, rig die apostel hom volgens 3:1

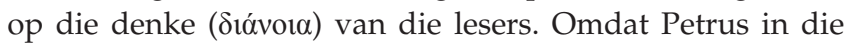
onmiddellike konteks van 3:1-2 die lesers in hulle denke lei met betrekking tot die standpunte van die leraars-spotters (vgl. 3:3-5), kan aanvaar word dat Petrus die woord Sióvola in 3:1 in die semantiese veld 'dink', in die subdomein 'om te dink, denke', en vir die betekenis van "n spesifieke wyse van dink' gebruik (Louw \& Nida 1988:350). Die apostel wil dus die lesers, volgens $3: 1$, tot 'n spesifieke denkwyse lei.

Petrus dui in 3:1, met die byvoeglike naamwoord 'suiwer' ( $\varepsilon \grave{i} \lambda \iota \kappa \rho v \tilde{\eta})$ aan wat die wyse van dink is wat hy vir die lesers in die oog het. Die woord عìıкрıv́s word gebruik vir die betekenis 'om ernstig te wees en wel in die opsig van suiwer motiewe' (Louw \& Nida 1988:747). Saam met Green (2008:311) kan aanvaar word dat die skrywer met die frase

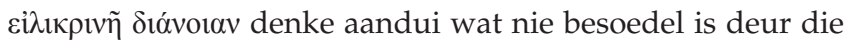
valsheid van die leraars-spotters nie.

Petrus vermeld nie uitdruklik in 3:1-2 waaroor die lesers suiwer denke moet hê nie. Hy verwys egter na die profete en apostels wanneer hy met die aoristiese infinitief $\mu \nu \eta \sigma \theta \tilde{\eta} v \alpha \iota$ in 3:2, op die gevolg (vgl. Jordaan 2014:34) van suiwer denke wys. Dit gee 'n aanduiding dat hy in 3:2 oor suiwer denke aangaande die profete en apostels handel. ${ }^{7}$ Dit word bevestig deur die feit dat Petrus in 2 Petrus in verskeie van die gedagte-eenhede in die brief, aandag gee aan die profete en die apostels. Petrus beklemtoon in die besonder die feit dat die profete en die apostels mense is wat dit verkondig het wat God en Jesus Christus aan hulle geopenbaar het. Reeds in gedagte-eenhede 1:1-2 beklemtoon hy dat hy en die ander apostels geloof verkry het $(\lambda \alpha \gamma \chi \alpha ́ v \omega)$ deur die geregtigheid van Jesus Christus as hulle God en Verlosser (vgl. Callan 2020:24-25; Van Houwelingen 1993:28-29). Wanneer Petrus in gedagte-eenheid 1:3-11 'n opsomming van sy leer gee, maak hy dit duidelik dat Jesus Christus hom en die ander

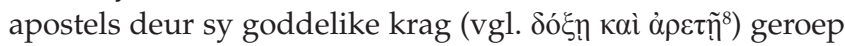
het, en aan hulle heerlike beloftes gegee het wat hulle moes verkondig (Breed 2021). In gedagte-eenheid 1:12-15 is Petrus se roeping en opdrag as apostel indirek ter sprake, wanneer hy noem dat Jesus Christus aan hom bekend gemaak het dat sy tentwoning binnekort afgebreek sou word. Petrus verwys daarmee na die gebeure wat in Johannes 21:18 opgeteken is toe Jesus bekend gemaak het dat Petrus ' $n$ gewelddadige dood sou sterf (Kistemaker 1987:261-262). In gedagteeenheid 1:16-21 beklemtoon Petrus dat hy en die ander twee apostels op die berg van verheerliking (vgl. Mt 17:1-5; Mk 9:2-3; Lk 9:28-36) oog- en oorgetuies was van dit wat God aangaande Jesus Christus geopenbaar het. Hy bring ook die profete in die gedagte-eenheid ter sprake as hy op die

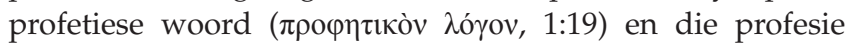
(

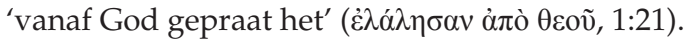

Petrus neem die gedagte dat die profete en apostels se verkondiging aan hulle geopenbaar is, weer in 3:2 op wanneer hy na die woorde van die heilige profete ( $\tau \tilde{\omega} v \mathrm{\alpha} \gamma \dot{\gamma} \omega \mathrm{v}$ $\pi \rho \circ \varphi \eta \tau \tilde{\omega} v)$ en die gebod van die apostels ( $\tau \tilde{\Upsilon} \varsigma \tau \tilde{\omega} v \dot{\alpha} \pi \circ \sigma \tau o ́ \lambda \omega v)$ verwys. "A $\gamma 10 \varsigma$ word in 3:2 nie gebruik om die 'moreel en etiese kwaliteite' (vgl. Louw \& Nida 1988:745) van die profete aan te dui nie. Hy gebruik örios in die betekenisveld 'religieuse aktiwiteite', in die subdomein 'afgesonder', vir die betekenis 'om afgesonder te wees vir diens aan God' (Louw \& Nida 1988:539). In 3:2 word dit duidelik gemaak dat die profete mense was wat vir diens aan God afgesonder was.

Die woorde wat voorheen volgens 3:2 deur die profete uitgespreek is, was in diens van God gedoen. Petrus verbind verder die apostels in 3:2 uitdruklik met Jesus Christus. Die gebod ( $\dot{\varepsilon} v \tau 0 \lambda \eta ́)$ waarna in 3:2 verwys word, is nie net die

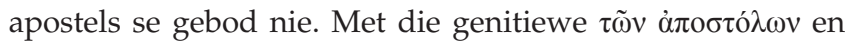

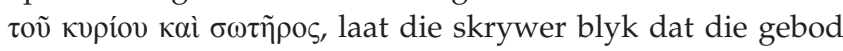
wat die apostels verkondig het, sy oorsprong by Jesus Christus het (Davids 2006:261).

Uit die voorgaande gegewens kan die gevolgtrekking gemaak word dat Petrus, volgens 3:1-2, die lesers wil lei om suiwer oor die profete en die apostels te dink. Die lesers moet weet dat die profete en die apostels mense is wat deur God en Jesus Christus geroep is, en dat dit wat hulle verkondig het, aan hulle geopenbaar is.

Wanneer Petrus die lesers in 3:1-2 lei om suiwer oor die profete en die apostels te dink, hou dit ook in dat hulle suiwer sal dink oor die leraars-spotters. In 2:1 beklemtoon Petrus, met die woord $\pi \alpha \rho \varepsilon \iota \sigma \alpha ́ \gamma \omega$, dat die leraars-spotters ' $n$ vreemde leer verkondig. Die woord $\pi \alpha \rho \varepsilon \imath \sigma \alpha ́ \gamma \omega$ in 2:1, dui die betekenis aan 'om te veroorsaak dat iets gebeur deur faktore van buite in te bring' (Louw \& Nida 1988:163). Dit wat die 8.Die twee woorde $\delta$ ó $\alpha$ en á $\rho \varepsilon t n$ word in $1: 3$ gebruik om saam die manifestasie van goddelik krag aan te dui (Bauckham 1983:178) 
leraars-spotters leer, kom van buite. Teenoor die mense wat hulle verkondiging van buite wil inbring, noem Petrus in 3:2

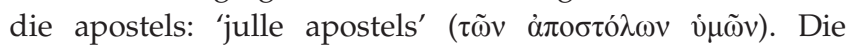
apostels is mense wat deur Jesus Christus - Hy wat die lesers as die Here en Verlosser ( gestuur is en daarom die lesers se apostels is.

Dit sou ingrypende gevolge vir die lesers inhou indien die leraars-spotters hulle kon oortuig dat die profete en apostels dit wat hulle verkondig het, nie deur openbaring ontvang het nie. As die profete en die apostels bloot hulle eie denke verkondig het, sou alles wat die lesers geglo het, onder verdenking wees.

Petrus dui ook aan op watter wyse hy wil sorg dat die lesers steeds suiwer oor die profete en die apostels dink. Hy wil

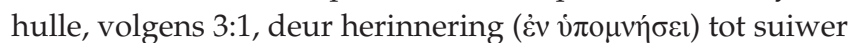
denke opwek. Die woord vंлó $\mu v \eta \sigma ı \varsigma$ word volgens Louw en Nida (1988:347), vir die betekenis 'om te veroorsaak dat inligting weer uit die geheue opgeroep word en dat opnuut daaroor gedink word' gebruik. Deur sy tweede brief wil Petrus sorg dat die lesers opnuut inligting oor die profete en apostels uit hulle geheue sal oproep, en dit nuut bedink. Midde in die druk wat die leraars-spotters op hulle plaas, moet dit die lesers helder voor oë bly dat die profete en apostels, anders as die leraars-spotters, alleen verkondig het wat aan hulle geopenbaar is.

Dit is opmerklik dat die profete en apostels ook vandag nog onder verdenking gebring word. Dawkins (2006:330) beskou die 'Doubting Thomas', in teenstelling met die ander apostels, in 'n positiewe lig. Anders as Thomas, het die res van die apostels nie vir bewyse van die opstanding gevra nie. Hitchens (2007) bring die geldigheid van die goddelike openbaring onder verdenking as hy verwys na:

The apparent tendency of the Almighty to reveal himself only to unlettered and quasi-historical individuals, in regions of Middle Eastern wasteland that were long the home of idol worship and superstition, and in many instances already littered with existing prophecies. (p. 98)

Hy kom tot die gevolgtrekking dat baie van die openbarings 'hopelessly inconsistent' is, en is daarom oortuig 'that some of them are false and illusory'. Harris (2011b:57) aanvaar nie dat dit wat in die Nuwe-Testamentiese bedeling geopenbaar is, die openbaring van die Ou Testament bevestig nie. Hy vra: 'Wouldn't it have been within the power of any mortal to write a book that confirms the predictions of a previous book?'

Bogenoemde laat blyk hoe belangrik dit is dat gelowiges suiwer sal dink oor die besondere plek van die $\mathrm{Ou}$ Testamentiese profete en Jesus Christus se apostels. Gelowiges moet deur herinnering (bv. in die prediking, huisbesoeke en kategese) gelei word om suiwer te dink oor die profete en die apostels. Hulle moet met sekerheid weet dat dit wat die profete en die apostels verkondig het, en in die Skrif opgeteken is, deur God en Jesus Christus geopenbaar is.
Christene moet nie deur die vals verkondiging van mense daaraan twyfel nie, naamlik dat 'God deur sy besondere sorg vir ons en ons saligheid, sy dienaars, die profete en apostels, beveel om sy geopenbaarde Woord op skrif te stel ...' (Nederlandse Geloofsbelydenis, artikel 3). Gelowiges moet, wanneer hulle hul op die Skrif beroep, weet dat dit wat hulle glo, 'volgens die wyse besluit van God, deur die profete, deur Christus self en deur die apostels in sowel die $\mathrm{Ou}$ as die Nuwe Testament verkondig' is (Dordtse Leerreëls, Hoofstuk 1, artikel 14).

\section{Suiwer denke en onthou}

Petrus dui in 3:2, met die aoristies passiewe infinitief $\mu \nu \eta \sigma \theta \tilde{\eta} v \alpha$, die gevolg (vgl. bo) indien die lesers suiwer sou dink. Wanneer hulle suiwer dink, sal hulle onthou. Hoewel

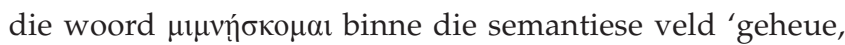
oproep van inligting' in vier verskillende sub-domeine gebruik kan word (Louw \& Nida 1988:346), kan aanvaar word dat Petrus dit in 3:2 in die sub-domein 'weer oproep van inligting en reageer met gepaste aksie', gebruik en wel in die betekenis: 'weer oproep van inligting en om as gevolg daarvan op 'n gepaste manier op te tree' (Louw \& Nida 1988:348). Petrus toon immers in 3:3-9 vir die lesers aan wat die gepaste reaksie, in die lig van die leraars-spotters se spot en optrede, behoort te wees. As die lesers dus, volgens 3:1-2, suiwer dink oor die profete en die apostels, sal hulle sekere inligting weer uit hulle geheue oproep en dan gepas kan optree.

Die inligting wat die lesers sal onthou, is volgens 3:2 eerstens die woorde ( $\dot{\rho} \tilde{\eta} \mu \alpha)$ van die profete. Petrus noem nie in 3:2 uitdruklik na watter woorde van die profete hy verwys nie. In die gedeelte wat op 3:2 volg, word die koms van die Here en die oordeel aan die orde gestel. Dit laat blyk dat Petrus met $\dot{\rho} \tilde{\mu} \alpha$ na die profesieë in die $\mathrm{Ou}$ Testament verwys waar God se toekomstige oordeel vermeld word, byvoorbeeld Jesaja 66:15-15, Habakuk 2:3 en Maleagi 3:1-2 (Van Houwelingen 1993:80). In verband met die vraag $\pi$ oṽ $\dot{\sigma} \tau \tau$ v van die leraars-spotters, wys Vögtle (1970:125-126) op die vraag in Psalm 42:11, Jeremia 17:15 en Maleagi 2:17.

Daar kan afgelei word dat Petrus, wanneer hy in 3:2 na die woorde van die profete verwys, meer as net die woorde van profete soos Jesaja en Maleagi in gedagte het. Hy sluit die hele Ou Testament in (vgl. Reese 2007:144-146). Hy wys die lesers immers in 3:5 op die skepping soos vermeld in Genesis 1, Psalms 33:6-7, 136:5-6 en Spreuke 8:24-29. In 3:6 noem hy die sondvloed soos vermeld in Genesis 6-8. In 1:8 beroep hy hom op Psalm 90:4 (LXX 89:4) (Davids 2006:275; Watson \& Callen 2012:208).

Soos reeds gemeld, wil Petrus volgens 3:2 ook dat die lesers

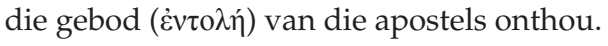

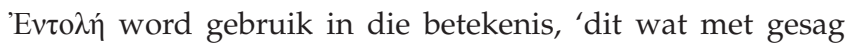

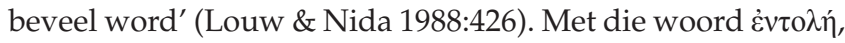
beklemtoon Petrus dus die feit dat die verkondiging van die 
apostels gehoorsaamheid eis. Daar is reeds gewys op die verklaring dat die gebod van die apostels volgens 3:2 ook die gebod van die Here en Verlosser is. Die gesag waarmee die apostels beveel, is die gesag van die Here en Verlosser. Wie die apostels se gebod verwerp, verwerp die gesag van die Here en Verlosser se gebod.

Soos reeds aangedui, toon Petrus in 3:5-8 in besonderhede wat 'n gepaste reaksie sou wees op die spot van die leraars-spotters. Hy toon uit die woorde van die profete uit die Ou Testament - die leraars-spotters se valsheid aan. Die spotters het volgens 3:4 spottend gevra waar die belofte van sy koms is, en beweer dat alles, sedert die vaders ontslaap het, dieselfde bly soos dit van die begin van die skepping af was. Uit die Ou Testament is dit duidelik dat hulle sekere feite in die geskiedenis buite rekening gelaat het. Die apostel wys onder meer op die skepping soos vermeld word in Genesis, Psalms en Spreuke (soos reeds genoem), die sondvloed soos dit beskryf word in Genesis 6-8 en op die toekomstige oordeel deur vuur wat in Deuteronomium 32:22, Jesaja. 34:4 en 66:15-16, Sefanja 1:18 en Maleagi. 1:4 vermeld word (Van Houwelingen 1993:82-85). In 3:8 wys hy daarop, in antwoord op die gespot van die leraars, dat God se tyd en mense se tyd nie dieselfde is nie (Donelson 2010:273-274).

Dit blyk dat Petrus in 3:3-8 die weg aandui hoe die lesers, indien hulle vars en nuut kennis dra van dit wat God in sowel die Ou Testamentiese bedeling as in die NuweTestamentiese bedeling geopenbaar het, gepas kan reageer op die valse verkondiging van die leraars-spotters.

Christene mag ook vandag daarop reken dat hulle met kennis en insig in God se openbaring in die Ou en die Nuwe Testament, gepas sal kan reageer wanneer standpunte wat aan hulle opgedring word, dreig om hulle van hulle standvastigheid in die geloof te beroof.

Twee voorbeelde van standpunte uit die geledere van die Nuwe Ateïste, waarmee gelowiges gekonfronteer word en wat van gelowiges gepaste reaksie vereis, word vervolgens kortliks aangedui. Die voorbeelde word beperk, deur aandag te gee aan twee sake wat in 2 Petrus aan die orde is. Omdat die artikel nie apologeties van aard is nie, word net enkele gedagtes uit 2 Petrus in antwoord op die standpunte van Nuwe Ateïste gegee. Daar word wel volledigheidshalwe na Christenskrywers verwys wat gepas in besonderhede op die spesifieke standpunte van die Nuwe Ateïste uit die Skrif reageer het.

Voorbeeld een: Geloof as 'n 'successful brain washer in its own favor'.

Dawkins (2006:330) beskryf geloof as 'n 'succesfull brain washer in its own favor'. Volgens hom is geloof 'n gemoedstoestand ('state of mind') wat mense daartoe lei om iets te glo, ondanks die feit dat daar geen bewyse voor is nie. Geloof kwalifiseer na sy mening as 'n soort geestesongesteldheid. Vir Harris (2005) is geloof:
The mortar that fills the cracks in the evidence and the gaps in the logic, and thus it is faith that keeps the whole terrible edifice of religious certainty still looming dangerously over our world. (p. 233)

Harris (2005:23) sê ook verder dat 'every religion preaches the truth of propositions for which it has no evidence'. Dennett (2006:311) stel gelowiges voor as mense wat nie in feite belangstel nie. Volgens hom gee gelowiges gehoor aan die oproep: 'Let's just close our eyes, trust to tradition, and wing it. Let's just take it on faith that religion is the key - or one of the keys - to our salvation'. Vir sy lesers sê hy dan 'How can I quarrel with faith (for heaven's sake)? Blind faith? Please. Think'.

Wanneer Petrus die doel van sy skrywe in 3:2 uiteensit, naamlik dat die lesers suiwer moet dink en die woorde van die profete en die gebod van die apostels moet onthou, wil hy nie die lesers oortuig om blindweg maar net te aanvaar wat aan hulle verkondig is nie. Hy hou in sy brief juis aan die lesers bewyse voor. Soos bo genoem, handel Petrus heel aan die begin van die brief oor die betroubaarheid van die apostels. Breed (2021) toon uit 1:3 aan dat Jesus Christus sy apostels op ' $n$ besondere manier geroep het. Hulle roeping ( $v g 1 \kappa a \lambda \varepsilon ́ \omega$ in 1:3) het behels dat hulle die manifestasie van

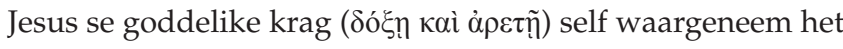
(vgl. die afdeling: Die denke van die lesers en herinnering). In 1:16-18 laat die skrywer blyk dat dit wat die apostels aan die lesers oor die koms van Jesus Christus verkondig het, op dit berus wat God aangaande Jesus Christus geopenbaar het. Uit dit wat die apostels gesien en gehoor het (vgl. غ̇лó $\pi \tau\rceil \varsigma$ en

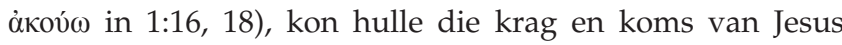
Christus bekend maak. Petrus vereis nie van sy lesers 'n daad van 'brainwashing' nie.

Omdat die Nuwe Ateïste glo dat God nie bestaan nie, verwerp hulle by voorbaat die getuienisse van die oog- en oorgetuies. As naturaliste is die natuur vir hulle al wat bestaan. Die naturalis glo dat daar niks en niemand buite die natuur is nie, en dat daar geen inmenging van buite op die sigbare werklikheid is nie (Haught 2008:10; Lennox 2011a:93). Die naturalis verabsoluteer dus die sigbare werklikheid (Nürnberger 2011:174-175). Nürnberger beklemtoon in hierdie verband 'n belangrik feit, naamlik dat die verabsolutering van die sigbare werklikheid nie op 'n wetenskaplike bevinding berus nie. Dit is 'a metaphysical assumption'.

Uit 2 Petrus kan afgelei word dat die heelal nie die enigste kenbron is wat die mens tot sy beskikking het nie.

In antwoord op die leraars-spotters wat beweer het dat God nie by die skepping betrokke is nie, en dat Hy nie sal oordeel nie (Neyrey 1980:414-420), wys Petrus die lesers byvoorbeeld in 3:3-5 op die gebeure tydens die skepping en die sondvloed soos dit in die Ou Testament opgeteken is (vgl. Suiwer denke en onthou, hier bo). Uit 2 Petrus blyk dit dat Christene, anders as die Nuwe Ateïste, op grond van die Skrif, twee kenbronne erken, naamlik God se skepping en God se Woord. Mense 
wat hulle ondersoek alleen tot die sigbare werklikheid beperk, sal soos die leraars-spotters wat God se openbaring verwerp het (Bauckham 1983:288), die volle waarheid wat God openbaar, nie vind nie.

Twee areas wat byvoorbeeld buite die skopus van die natuurwetenskappe lê, so toon McGrath (2015:234-247RR) aan, 'are the non-empirical notions of value and meaning. These cannot be read off the world or measured as if they were constants of nature'.

Terwyl Harris (2011a:30) en Hitchens (2007:52) glo dat die wetenskap sonder religie, die mens in staat kan stel om te bepaal wat die regte en verkeerde antwoorde op morele vrae is, toon Turek (2014:231-284) aan dat alleen 'an unchanging authoritative being' wat objektiewe moraliteit kan voorskryf en handhaaf, 'n voldoende standaard bied. Naturaliste wat die sigbare werklikheid verabsoluteer en God se bestaan ontken, het geen 'fail-safe' kriteria van wat reg en verkeerd is nie (vgl. Haught 2008:65-77; Lennox 2011b:97-116). Dawkins, wat beskryf word as die 'most truculent exponent of Darwinian theory' (Barr 2016:32), probeer aandui dat die mens tog in staat is om sonder God objektiewe moraliteit te bepaal. Dawkins (2003:10-11) sê dat, hoewel hy as wetenskaplike Darwinisme ondersteun, hy ' $\mathrm{n}$ 'passionate anti-Darwinian' is, 'when it comes to politics and how we should conduct our human affairs'. Volgens hom het evolusie aan die mens 'n verstand gegee wat die mens lei tot die 'understanding its own provenance, of deploring the moral implications and of fighting against them'. Barr (2016:34) toon egter aan dat Dawkins se argument nie gewig dra nie. Dawkins gee nie die rede waarom die mens die geveg teen die morele implikasies van 'nature's imperatives' sal aanpak nie, en ook nie watter objektiewe morele standaarde in die 'fighting' gebruik sal word nie. Dit blyk dat Turek (2014:260) reg is wanneer hy sê dat mense wat Darwinisme onderskryf, maar die 'survival-of-thefittest ethic' verwerp, 'don't realize that they are stealing a moral law from God'.

Voorbeeld twee: Die God van die Ou Testament as 'the most unpleasant character in all fiction'.

By die Nuwe Ateïste is dit veral God se selfopenbaring in die Ou Testament wat onder skoot kom (Imbert 2013:51-53). Dawkins (2009) sê:

The God of the Old Testament is arguably the most unpleasant character in all fiction: jealous and proud of it; a petty, unjust, unforgiving control-freak; a vindictive, bloodthirsty ethnic cleanser; a misogynistic, homophobic, racist, infanticidal, genocidal, filicidal, pestilential, megalomaniacal, sadomasochistic, capriciously malevolent bully. (p. 51)

Dennett (2006:206) skets God soos volg 'The Old Testament Jehovah, or Yahweh, was quite definitely a super-man (a He, not a She) who could take sides in battles, and be both jealous and wrathful.' Dennetty (2006:265) verwys minagtend na die God van die Ou Testament: 'Part of what makes Jehovah such a fascinating participant in stories of the Old Testament is His kinglike jealousy and pride, and His great appetite for praise and sacrifices'.

Die vraag sou wees of gelowiges wat met kennis van wat God in die $\mathrm{Ou}$ en Nuwe Testamentiese bedeling openbaar het, gepas hierop sou kon reageer. Is die beskuldiging van die Nuwe Ateïste dat die God van die Ou Testament ' $n$ 'moral monster' (vgl. Copan 2011:210) is, geldig? Copan (2011:27-222; vgl. ook Lennox 2011b:117-144) gee in antwoord op hierdie beskuldiging, in besonderhede aandag aan moeilik verklaarbare gedeeltes in die Ou Testament. Hy wys daarop dat die Nuwe Ateïste in hulle stellings oor die God van die Ou Testament, nie erns maak met die 'historical context' en die 'broader biblical canon' (Copan 2011:23) van die moeilike gedeeltes in die Ou Testament nie. Copan bied 'n duidelike perspektief op hierdie gedeeltes. 'The ultimate resolution', op hierdie gedeeltes, sê Copan (2011:221-222) 'is found in God's clarifying Word to us and the One who became flesh and lived among us, who died and rose again on our behalf.' Hy stel teenoor die Nuwe Ateïste wat God as 'n morele monster voorhou, dat God volgens die $\mathrm{Ou}$ Testament enersyds 'a holy God to be reckoned with' is en andersyds, 'a loving, self-sacrificing God who invites us to be reconciled to him'.

Petrus handel in 2:4-8 ook oor gebeure wat in die $\mathrm{Ou}$ Testament opgeteken is. Hy maak in 2:9, uit die $\mathrm{Ou}$ Testamentiese gedeeltes, spesifieke gevolgtrekkings aangaande die Here. Hy kom eerstens met Noag (2:5) en Lot (2:7-8) in gedagte, tot die gevolgtrekking dat die Here

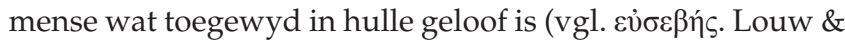

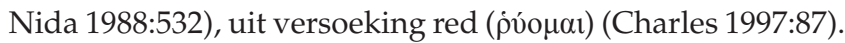
Die gevolgtrekking wat Petrus in 2:9 met betrekking tot die onregverdiges maak, is egter as antwoord op die Nuwe Ateïste van belang. Op grond van die Here se optrede teenoor die engele wat gesondig het ( $\alpha \gamma \gamma \varepsilon \dot{\lambda} \omega v \dot{\alpha} \mu \alpha \rho \tau \eta \sigma \alpha ́ v \tau \omega v$,

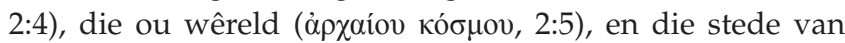

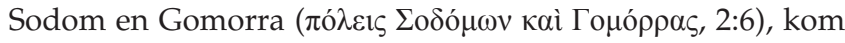
Petrus tot die gevolgtrekking dat die Here die onregverdiges

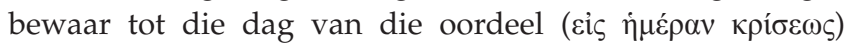
(Charles 1997:168). Die woord кpíøı in 2:9, wys op straf met die implikasie dat die persoon wat gestraf word, skuldig bevind is (Louw \& Nida 1988:489). Wat met die dag van die oordeel gaan gebeur, word met die woord, ко $\lambda \alpha \dot{\zeta} \omega$, aangedui en word gebruik om straf wat intense lyding inhou, aan te

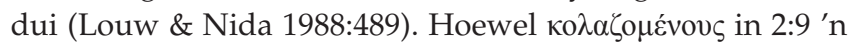
praesens deelwoord is, wys dit op toekomstige gebeure (Bauckham 1983:254; Green 1987:114 2008:264-265). Die onregverdiges word bewaar tot die dag van die oordeel en dan sal hulle intense lyding ondergaan.

Dit blyk dat Petrus die voorbeelde van die engele, die mense in die tyd van Noag, en die stede van Sodom en Gomorra, as 'n waarskuwing gee. Dit is 'n waarskuwing vir sowel die lesers as die leraars-spotters. Wie in ongeloof volhard met ' $n$ onregverdige lewe, moet weet dat die Here hulle bewaar vir sy oordeel, waarin hulle wat skuldig bevind is, intense lyding sal ondergaan. Daar moet ook in gedagte gehou word dat die komende oordeel telkens in 2 Petrus 
beklemtoon word (vgl. byvoorbeeld 2:1, 3, 12, 17: 3:10, 12). Die vraag sou wees of dit wat die apostel in 2:9 vanuit die Ou Testament oor die Here en sy oordeel sê, nie die Nuwe Ateïste in hulle stellings oor die God van die Ou Testament ondersteun nie. Die vraag is: 'Dui dit wat in 2:9 van die Here en sy oordeel oor mense gesê word, Hom nie soos Dawkins beweer, as ['n] onregverdige, onvergewensgesinde, wispelturige, boosaardige boelie aan nie?'

Daar moet eerstens gelet word op die feit dat Petrus, voordat hy handel oor die Ou Testamentiese gedeeltes (2:4-8), die vals leraars in 1:1-2 beskryf. In 2:1 is die oordeel oor die leraars-spotters ook ter sprake wanneer Petrus na hulle vernietiging ( $\alpha \dot{\pi} \omega \lambda \varepsilon 1 \alpha$, Louw \& Nida 1988:232) verwys.

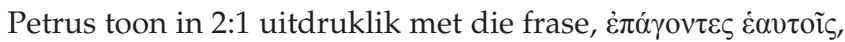
aan dat die leraars-spotters self hulle vernietiging bewerk. Hoe die leraars-spotters hulle vernietiging bewerk, dui Petrus ook in 2:1 aan. Hy sê dat hulle die Here wat hulle

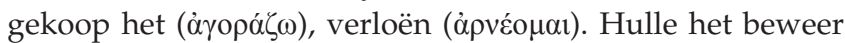
dat hulle deur die Here gekoop is. Hulle optrede het egter getoon dat dit ' $n$ valse bewering is. Hulle was nie werklik deel van die mense wat deur die Here gekoop is nie (Schreiner 2003:329).

Petrus bring in 2:1 die vrykoop van die leraars-spotters en hulle vernietiging met mekaar in verband. Apvéopal word in 2:1 gebruik vir die betekenis 'om iemand se vryheid te bewerk deur middele wat groot koste inhou vir die individu wat die vryheid bewerk' (Louw \& Nida 1988:488). Dit blyk dat die groot koste wat in 2:1 ter sprake is, 'n verwysing is na

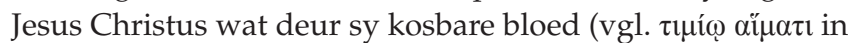
1 Petrus $1: 19)^{9}$ ) mense vrygekoop het van God se oordeel. Die feit dat die Here die onregverdiges bewaar tot die dag van die oordeel, en dat hulle dan intense lyding sal ondergaan, moet verstaan word in die lig daarvan dat hierdie mense die Here verloën het - dié Here wat sondige mense uit liefde met sy kosbare bloed vrygekoop het van God se regverdige oordeel. Wie God se oordeel oor onregverdiges sodanig verstaan, sal weet dat die Nuwe Ateïste eerstens geen begrip van God se genade het nie. Hulle het ook geen begrip van sy regverdigheid en van die gevolge vir elke mens wat God se genade verwerp, nie. Daar kan met Copan saamgestem word: God is 'a holy God to be reckoned with'.

In die voorbeeld wat Petrus in 2:5 van die sondvloed gee, is dit opmerklik dat Noag ' $n$ prediker van geregtigheid ( Genesis so genoem nie. Daar word wel in Genesis 6:9 en 12 (LXX) na hom as 'n regverdige mens ( $\alpha v \theta \rho \omega \pi$ o verwys. In Genesis 6:11 (LXX) word vermeld dat die aarde, in die tyd van Noag, gevul was met ongeregtigheid ( $\dot{\varepsilon} \pi \lambda \eta \dot{\sigma} \theta \eta$ $\left.\dot{\eta} \gamma \tilde{\eta} \dot{\alpha} \delta ı \kappa^{\prime} \alpha \varsigma\right)$. Noag se regverdigheid was vir mense sigbaar, deurdat hy in gehoorsaamheid aan die Here volhard het om die ark te bou - die ark wat 'n teken was van die

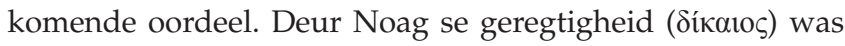
hy 'n prediker vir die mense van sy tyd, wie se lewens gekenmerk is deur ongeregtigheid ( $\left.\alpha \dot{\delta} \iota \kappa^{\prime} \alpha\right)$. Voor die oordeel van die sondvloed voltrek is, het die mense wie se lewens vol ongeregtigheid was, geleentheid gehad om tot inkeer te kom.

Petrus beklemtoon ook elders in die brief dat die Here 'n tyd van genade gee waarin mense tot bekering kan kom. In 3:9 ontken Petrus dat die Here die belofte (van die Here se koms en die oordeel - vgl. Charles 1997:46) uitstel. Hy sê dat die Here nie wil hê dat iemand verlore gaan nie. Hy wil hê dat almal hulle moet bekeer. Ook in 3:15 val die klem op die Here se genade. Petrus sê dat mense die lankmoedigheid van die Here as 'n geleentheid tot verlossing moet ag. Anders as die oortuiging van die Nuwe Ateïste, dui Petrus uit die Ou Testament aan dat die Here nie onvergewensgesind en onregverdig is nie. Hy roep elke mens tot bekering en $\mathrm{Hy}$ vergewe wanneer mense tot inkeer kom. Die God van die Ou Testament is inderdaad 'a loving, self-sacrificing God who invites us to be reconciled to him' (Copan 2019:222).

\section{Slotsom}

Die apostel Petrus gee in 2 Petrus leiding aan sy lesers wat onder druk van die leraars-spotters was, en die vastigheid in hulle geloof kon verloor. Uit die eksegese en hermeneuse van 3:1-2 blyk die volgende:

- Gelowiges verkeer in hulle geloof vandag steeds soos Petrus se eerste lesers, onder groot druk van mense wat hulle geloof bevraagteken en selfs bespotlik voorstel.

- Soos Petrus se eerste lesers, het gelowiges vandag nog leiding nodig sodat hulle nie hulle vastigheid in die geloof verloor nie.

- Dit is van groot belang dat gelowiges sekerheid sal hê, dat die verkondiging van die profete en die apostels soos dit in die Bybel opgeteken is, nie op die profete en apostels se eie denke berus nie. Dit wat hulle verkondig het, is deur God en Jesus Christus aan hulle geopenbaar. Hierdie sekerheid moet deur herinnering by gelowiges ingeskerp word.

- Wanneer gelowiges suiwer dink oor die verkondiging van die profete en apostels, en hierdie verkondiging vars en nuut onthou, mag hulle daarop reken dat hulle gepas sal kan reageer wanneer hulle met ateïstiese standpunte gekonfronteer word.

- Gelowiges wat die verkondiging van die profete en apostels nuut onthou, sou byvoorbeeld kon aantoon dat die Skrif nie geloof as 'n daad van 'brainwashing' voorhou nie. Petrus wys immers vir sy lesers daarop dat die apostels oog- en oorgetuies was van God se openbaring. Gelowiges sou kon aantoon dat die naturaliste, wat die bestaan van enigiets buite die natuur ontken, die natuur verabsoluteer. Petrus laat in sy brief blyk dat die mens God se skepping én die Skrif as betroubare kenbron ontvang het.

- Op die voorstelling dat die God van die Ou Testament 'n 'moral monster' is, sou gelowiges kon antwoord dat hierdie voorstelling vals is. Petrus toon uit die $\mathrm{Ou}$ Testament aan dat gelowiges mag reken op God se redding wanneer hulle onder druk verkeer. Dit is ook 
uit 2 Petrus duidelik dat God ongelowiges tot geloof roep. Hulle wat egter God se genade in Jesus Christus verwerp, bring God se oordeel oor hulleself. Hulle sal die regverdige oordeel van God ontvang.

\section{Erkenning \\ Mededingende belange}

Die outeur verklaar dat daar geen finansiële of persoonlike verbintenis is met enige party wat hom nadelig kon beïnvloed in die skryf van hierdie artikel nie.

\section{Outersbydrae}

D.G.B. is die enigste outeur betrokke by die skryf van hierdie artikel.

\section{Etiese oorwegings}

Hierdie artikel volg alle etiese standaarde vir navorsing.

\section{Befondsing}

Hierdie navorsing het geen spesifieke toekenning ontvang van enige befondsingsagentskap in die openbare, kommersiële of nie-winsgewende sektore.

\section{Data beskikbaarheid}

Die outeur bevestig dat die data wat die bevindings van hierdie studie ondersteun, beskikbaar is in die artikel.

\section{Vrywaring}

Die sienings en menings wat in hierdie artikel uitgedruk word, is dié van die outeur en weerspieël nie noodwendig die amptelike beleid of posisie van enige geaffilieerde verwantskap van die outeur nie.

\section{Literatuurverwysings}

Angier, N., 2004, “"The end of faith": Against toleration', New York Times Sunday, viewed 20 January 2021, from https://www.nytimes.com/2004/09/05/books/ review/the-end-of-faith-against-toleration.html

Barr, S., 2016, The believing scientist: Essays on science and religion, Eerdmans, Grand Rapids, MI.

Bauckham, R.J., 1983, Jude, 2 Peter, Word Biblical Commentary, Waco, TX. (Word Biblical Commentary, vol. 50).

Blaising, C.A., 2012, 'The day of the Lord will come: An exposition of 2 Peter 3:1-18', Bibliotheca Sacra 169(October-December), 387-401.

Breed, D.G., 1994, 'Die kenmotief in 2 Petrus: 'n Eksegetiese studie', ThD proefskrif, PU vir $\mathrm{CHO}$, Potchefstroom.

Breed, D.G., 2021, 'Die betroubaarheid van die apostels en hulle getuienis volgens 2 Petrus 1:3-4 en die betekenis daarvan vir die geskrifte van die Nuwe Testament: ' $n$ Eksegetiese studie', Om gepubliseer te word in In die Skriflig/In Luce Verbi [Ter perse]

Breed, D.G., Van Rensburg, F.J. \& Jordaan, G.J.C., 2008, Manlik en vroulik in die kerk: Geslagtigheid en die besondere dienste, Potchefstroomse Teologiese Publikasies, Potchefstroom.

Callan, T., 2020, A voyage around the second letter of Peter: Collected essays, Pick Wick Publications, Eugene, OR.

Charles, J.D., 1997, 'Virtue amidst vice: The catalog of virtues in 2 Peter 1', Journal for the Study of the New Testament, Suppl. Ser. 150:1-210.

Coetzee, J.C., 1988, 'Gedagtestruktuurontleding en die eksegese van die Heilige Skrifte', in J.C. Coetzee (red.), Koninkryk, Gees en Woord, pp. 19-37, NG Kerkboekhandel, Pretoria.

Coetzee, J.C., De Klerk, B.J. \& Floor, L., 1980, 'Die hermeneuse van die Skrif met die oog op hedendaagse kerklik-etiese vraagstukke', In die Skriflig 14(54), 12-26. https://doi.org/10.4102/ids.v14i54.761
Copan, P., 2011, Is God a moral monster? Making sense of the Old Testament God, Baker Books, Grand Rapids, MI.

Copan, P. \& Craig, W.L., 2009, Contending with Christianity's critics: Answering new atheists and other objectors, B \& H Academic, Nashville, TN.

Davids, P.H., 2006, The letters of 2 Peter and Jude, Eerdmans, Grand Rapids, MI. (The Pillar New Testament Commentary).

Dawkins, R., 2003, A devil's chaplain: Reflections on hope, lies, science, and love, Houghton Mifflin, New York, NY.

Dawkins, R., 2006, The selfish gene, Oxford University Press, Oxford.

Dawkins, R., 2009, The God delusion, Transworld Publishers, London.

Dennett, D.C., 2006, Breaking the spell: Religion as a natural phenomenon, Penguin Books, New York, NY.

Donelson, L.R., 2010, 1 \& 2 Peter and Jude: A commentary, Westminster John Knox Press, Louisville, TN. (The New Testament Library).

Dordtse Leerreëls, 2003, 'Die Dordtse Leerreëls' in Gereformeerde Kerke in SuidAfrika, Psalmboek: Die berymde en omgedigte Psalms en ander Skrifberymings in gebruik by die Gereformeerde Kerke in Suid-Afrika', pp. 76-109, NG KerkUitgewers, Paarl.

Fee, D.G., 2009, New Testament exegesis: A handbook for students and pastors, Westminster John Knox Press, Louisville, TN.

Feser, E., 2013, 'The new atheists and the cosmological argument', Midwest Studies in Philosophy, 37(2013), 154-177. https://doi.org/10.1111/misp.12000

Gordon, D., 2008, 'Richard Dawkins and the God', Stimulus 16(2), 2-5.

Green, G., 2008, Jude and 2 Peter, Baker Academic, Grand Rapids, MI. (Baker Exegetical Commentary on the New Testament).

Green, J.B., 2006, 'Narrating the gospel in 1 and 2 Peter', Interpretation: A Journal of Bible and Theology 60(3), 262-277. https://doi.org/10.1177/002096430 606000303

Green, M., 1987, The second epistle general of Peter and the general epistle of Jude, Eerdmans, Grand Rapids, MI. (The Tyndale New Testament Commentaries).

Harris, P., 2019, The rage against the light: Why Christopher Hitchens was wrong, Resource Publications, Eugene, OR.

Harris, S., 2005, The end of faith: Religion, terror, and the future of reason, Norton, New York, NY.

Harris, S., 2011a, The moral landscape, Free Press, New York, NY.

Harris, S. 2011b, Letter to a Christian nation, EBook, Random House.

Haught, J.F., 2008, God and the new atheism: A critical response to Dawkins, Harris, and Hitchens, Westminster John Knox Press, Louisville, TN

Hitchens, C., 2007, God is not great: How religion poisons everything, Twelve Hachette Book Group, New York, NY.

Imbert, T., 2013, 'The end of reason: New Atheists and the Bible', European Journal of Theology 22(1), 50-64.

Johnson, A., 2013, 'An apology for the "New Atheism"', International Journal for Philosophy of Religion 73(1), 5-28. https://doi.org/10.1007/s11153-012-9350-9

Jordaan, G.J.C., 2014, Die binnewerk van Antieke Grieks: Die semantiek van grammatiese konstruksies: Handleiding vir eksegete en ander studente van Klassieke en Nuwe-Testamentiese Grieks, Potchefstroom Teologiese Publikasies, Potchefstroom.

Jordaan, G.J.C., Van Rensburg, F.J. \& Breed, D.G., 2011, 'Hermeneutiese vertrekpunte vir gereformeerde eksegese', In die Skriflig/In Luce Verbi 45(2/3), 225-258. https://doi.org/10.4102/ids.v45i2/3.14

Joseph, K., 2020, "To an unknown God": How religion proclaims what science worships', The Way 59(2), 51-54. https://doi.org/10.4324/9781003023371-7

Kistemaker, S.J., 1987, Exposition of the epistles of Peter and of the epistle of Jude, Evangelical Press, Hertfordshire. (New Testament Commentary).

Kruger, M.J., 1999, 'The authenticity of 2 Peter', Journal of the Evangelical Theological Society 42(4), 645-671.

Laing, J.D., 2011, 'The new atheists: Lessons for evangelicals', Southwestern Journal of Theology 54(1, Fall), 13-28.

Lennox, J.C., 2011a, God and Stephen Hawking: Whose design is it anyway? Lion Hudson, Oxford.

Lennox, J.C., 2011b, Gunning for God: Why the new atheists are missing the target, Lion Hudson, Oxford.

Louw, J.P. \& Nida, E.A., 1988, Greek-English lexicon of the New Testament based on semantic domains, vol. 1, United Bible Societies, New York, NY.

McGrath, A.E., 2015, Dawkins' God: From the selfish gene to the God delusion, John Wiley, West Sussex.

Moo, D.J., 2011, 2 Peter, Jude, Zondervan, Grand Rapids, MI. (The NIV Application commentary).

Nederlandse Geloofsbelydenis, 2003, 'Die Nederlandse Geloofsbelydenis' in Gereformeerde Kerke in Suid-Afrika (ed.), Psalmboek: Die berymde en omgedigte Psalms en ander Skrifberymings in gebruik by die Gereformeerde Kerke in SuidAfrika, pp. 5-32, NG Kerk-Uitgewers, Paarl.

Neyrey, J.H., 1980, 'The form and background of the polemic in 2 Peter', Journal of Biblical Literature 99(3), 407-431. https://doi.org/10.2307/3265374

Nürnberger, K., 2010, Richard Dawkins' God delusion: A repentant refutation, Xlibris, London. 
Nürnberger, K., 2011, Regaining sanity for the earth: Why science needs 'best faith' to be responsible. Why faith needs best science to be credible, Xlibris, London.

Reese, R.A., 2007, 2 Peter and Jude, Eerdmans, Grand Rapids, MI. (The two Horizons New Testament Commentary).

Schreiner, T.R., 2003, 1, 2 Peter, Jude, B \& H Publishing Group, Nashville, TN. (The New American Commentary).

Tolar, W.B., 2002, 'The grammatical-historical method', in B. Corley, S. Lemke \& G.I. Lovejoy (eds.), Biblical Hermeneutics: A comprehensive introduction to interpreting scripture, pp. 21-38, Broadman \& Holman Publishers, Nashville. TN

Turek, F., 2014, Stealing from God: Why atheists need God to make their case, NavPress, Corol Steam.
Van Houwelingen, P.H.R., 1993, 2 Petrus en Judas: Testament in tweevoud, Kok, Kampen. (Commentaar op het Nieuwe Testament).

Van Houwelingen, P.H.R., 2010, 'The authenticity of 2 Peter: Problems and possible solutions', European Journal of Theology 19(2), 119-129.

Vögtle, A., 1970, Das Neue Testament und die Zukunft des Kosmos, Patmos-Verlag, Düsseldorf.

Walsh, A., 2019, Answering the New Atheists: How science points to God and to the benefits of Christianity, Vernon Press, Wilmington, NC.

Watson, D.F. \& Callan, T., 2012, First and second Peter, Baker Academic, Grand Rapids, MI. (Paideia Commentaries on the New Testament).

Zenk, T., 2013, 'New Atheism', in S. Bullivant \& M. Ruse (eds.), The Oxford handbook of atheism, pp. 245-260, Oxford University Press, Oxford. 